\title{
Navigating a Wayward Path toward Public Engagement
}

\author{
Peter DelNero \\ Cornell University
}

\begin{abstract}
Graduate school is an intense period of identity formation, where scholars-in-training form the attitudes and values that shape their research. The extent to which students assimilate public engagement into their academic formation may depend on the system of beliefs that underpin their particular field of study. In some fields, public engagement disrupts the conventional forms of scholarship and elicits a peculiar tension. If graduate students are trained to think and act in certain ways, then what happens to people who choose to think and act differently in order to cultivate a community-engaged mindset? How can graduate students overcome a misalignment between their personal goals, values, and interests and those of their discipline? In this essay, I examine these questions through my experiences as a community-engaged doctoral student in biomedical engineering.
\end{abstract}

Graduate school represents a critical stage in the academic pipeline, where professional attitudes and priorities are internalized by future faculty and administrators. During graduate education, students construct the aspirations, commitments, and identities that ultimately define their careers. As such, there is growing appreciation for preparing graduate students for professional roles that advance the practice of community-engaged scholarship (Austin \& Barnes, 2005; Stanton, 2012). But what if graduate students are trained in departments that do not value or reward these activities? Will emerging scholars perpetuate traditional attitudes toward teaching, research, and service?

In this narrative, I reflect on my experience of disrupting a cycle of social reproduction in order to accommodate a community-engaged mindset. The article is autoethnographic in that I connect my personal experiences with an analysis of my academic culture (Ellis, 2004; Ellis, Adams, \& Bochner, 2011). I present this essay as a scholarly personal narrative (Nash \& Bradley, 2011); the italicized sections represent my personal experiences and interpretations.

While pursuing their degree, graduate students navigate an evolving sense of personal and professional self-concept. Through a process of socialization, students acquire specialized knowledge and skills, while coming to recognize the cultural norms, ideologies, and world views that characterize their profession (Gardner, 2008; O'Meara, 2008). At the same time, graduate students have entered a stage of self-authorship, where they exercise the capacity to define their own beliefs, identities, and social relations (Baxter Magolda, 2006). Students play an active role in shaping their academic formation while learning to navigate professional norms and boundaries.

I am a doctoral candidate in biomedical engineering, specializing in cancer biology. As a graduate student, I fall into an uncomfortable gap between advanced student and novice scholar. In addition to taking classes, I also teach, conduct research, and assume service roles at my institution. When I entered graduate school, I expected to receive instrumental training in biomedical research and become a credentialed professional in the field. During my first year, I quickly assimilated into the norms of my discipline.

Disciplinary norms are the values, behaviors, and responsibilities that characterize "business-asusual" in an academic community. Academia is a diverse profession, but there is an implicit code-ofconduct that governs the epistemic culture within each field (Margolis \& Romero, 1998). This culture is often invisible to new students, concealed within the latent assumptions and biases of the discipline. As discussed by the Carnegie Initiative on the Doctorate, graduate education is largely a process of becoming acculturated to these norms (Walker, Golde, Jones, Bueschel, \& Hutchings, 2008).

Jackson (1968) introduced the concept of a "hidden curriculum" to describe the cultural transmission that occurs within and beyond the classroom. The hidden curriculum is the way in which institutional systems "persist and reproduce themselves without being consciously recognized by the people involved" (Apple, 1982, p. 13). In graduate education, disciplinary norms play a substantial role in the socialization of emerging scholars, but they "remain an embedded and largely ignored element of academic life" (Gair \& Mullins, 2001, p. 27). 
As an engineering student, I inhabit a discipline where I perceive the culture to be relatively strict. Patterns of thought and behavior are enforced via institutional structures such as apprenticeship, peer-review, the curriculum, and the collective expectations of the community. The engineering identity, with its explicit maxim to "think like an engineer," is an unequivocal way of being.

Although socialization provides a stable mechanism for stewardship and knowledge transmission, the hidden curriculum can sometimes be problematic (Egan, 1989; Nyquist et al., 2010). For example, the apprenticeship model of doctoral training has been criticized for perpetuating institutional discrimination (Damrosch, 2006). When experts evaluate prospective candidates, they "tend to look for someone like themselves, missing the valuable talents of people who are different" (Lawrence \& Matsuda, 1997, pp. 100-101; Margolis \& Romero, 2001, p. 83).

Downey and Lucena (1997) connect the negative impact of socialization to the concept of "weeding out." During interviews, "students regularly asserted that the goal of certain courses was to "weed out' students. . . . For students who stayed, these and other courses also appeared to weed out part of themselves as persons [italics added]" (p. 126). Similarly, Weidman and colleagues (2001) reported that the principal conflict for many graduate students was the feeling that they must sacrifice their own interests and goals to fit the expectations and interests of their advisors. Students who embody nonconforming social or intellectual identities confront systematic resistance, which subverts efforts toward equity, innovation, and risk-taking.

Cech (2014) reported a "culture of disengagement" in engineering education, comprising a collection of ideologies that discourage civic awareness and activism. This culture is characterized by an exclusion of non-technical stakeholders in academic dialogue, the dismissal of public welfare concerns, and an inattention toward social justice, equity, and social responsibility (see also Cech \& Sherick, 2015). As a result of socializing to these norms, engineering students lose the ability to reflect on the broader context of their work; to define and prioritize social concerns; and to assess problems, methods, or outcomes from multiple perspectives. In essence, students learn to dissociate public impacts as tangential to their field of study (Cech).

My acculturation into the biomedical engineering community was disrupted by an emerging partnership with a local cancer support center, which I helped initiate during my second year of graduate school (see DelNero \& McGregor, 2017, From Patients to Partners). Our collaboration is logistically simple, comprising a monthly colloquium for patients, survivors, and students. Seminars are complemented by a variety of informal activities that facilitate dialogue between patients and scientists.

As my relationship with the cancer community grew stronger, it gradually infringed on my identity as an engineer. My priorities and attitudes toward research seemed misaligned with the expectations of my colleagues. For example, a faculty member once complained to me that the "broader impacts" criteria should be eliminated from the funding mechanisms of the National Science Foundation. The professor stated, "I don't write grants so that [my student] can do outreach. I'm training her to be a scientist, not a babysitter." According to this professor, broader impacts, such as public engagement activities, are a waste of time. Because of my involvement in the cancer community, I found myself becoming an outsider in my discipline.

In an analysis of participatory research, Nyden (2003) observed that "sometimes [academic] culture can be indifferent to community involvement; other times it is actually hostile" (pp. 577-578). For graduate students, "being in opposition does not simply mean confronting abstract ideas; frequently and most uncomfortably it means confronting one's professors" (Margolis \& Romero, 2001, p. 89). Given these circumstances, "successful" students are often those who readily assimilate to disciplinary paradigms, while students who re-define these paradigms have a more difficult experience (Gair \& Mullins, 2001; Strouse, 2014). In some cases, this environment might tacitly discourage civic engagement activities, social justice concerns, and the retention of graduate students who espouse them.

Cognitive dissonance is a painful but important element of disciplinary learning. But in my case, the cognitive dissonance between the discipline of engineering and community engagement evoked feelings of guilt, shame, and self-doubt. Through my academic training, I had internalized the belief that public engagement was outside the purview of engineering. My relationships with community members challenged my assumptions about the purpose, process, and products of biomedical engineering research. At the time, I was unable to articulate this dissonance, but I felt an overwhelming anxiety surrounding what I was coming to perceive as my deviant patterns of thought and behavior. My commitment to the community partnership violated my beliefs about what it meant to be an engineer.

Reflection, as a cornerstone of service-learning and with roots often attributed to the education theories of John Dewey (1910) and David Kolb (1984), is the vital link between experience and knowledge. 
In Where's the Learning in Service-Learning (Eyler \& Giles, 1999), reflective practices predicted learning outcomes associated with personal development, citizenship, problem-solving, and perspective transformation. In service-learning pedagogy, cognitive and emotional processes are inseparable dimensions of reflection (Felten, Gilchrist, \& Darby, 2006), both of which are essential for making meaning from experience.

Self-reflection was facilitated through my role in developing curriculum, writing grant proposals, and drafting manuscripts. Through this process, I learned how to tell my story, and I gained a deeper understanding of my experiences. By pursuing community-engaged activities, I felt I was "breaking the rules" of what an engineering student is "supposed to do." But ultimately, who decides how an engineer should think or behave? Why did I maintain the inexorable conviction that community engagement was verboten?

As I reflected on this, I arrived at Walt Kelly's startling conclusion: "We have met the enemy and he is us." I discovered that I was trapped by tunnelvision: I had internalized a system of values and beliefs from my discipline. But I also realized that I had the capacity to change those values and beliefs. This realization enabled me to construct a new, integrated concept of my professional identity: I thought I knew what it meant to be an engineer, but that was partly a myth. It's okay to be different.

According to Mezirow (1990), transformative learning "makes it possible for us to [ . . . ] become emancipated from our constraining habits of expectation and move to a perspective that permits interpretations which are more inclusive, differentiating, permeable, and integrative of experience" (p. 141). Transformative learning empowered me to step beyond my existing patterns of thought and behavior, and to extend the definition of my profession.

My involvement in public engagement transformed my perspective of graduate education. I am no longer the passive recipient of professional socialization. As a graduate student, I am responsible for my own academic development, including attentiveness toward the intellectual and social norms that permeate my discipline. I have agency to define the values, goals, and methods of my scholarship. I have an obligation to reflect on the usefulness of knowledge, the social consequences of my work, and its relation to the world beyond campus (Boyer, 1990). In short, I am a co-creator of the intellectual communities that I inhabit and an advocate for my ongoing formation as an engaged scholar.

In graduate education, students internalize the profession's concept of ethical behavior and social norms. If community dialogue is marginalized, emerging scholars will continue to define public engagement as irrelevant to the practice of their discipline. Conversely, graduate students are uniquely positioned to disrupt the cycle of assimilation and to cultivate an academic identity that accommodates public engagement. We can foster an intellectual community that "provides explicit emphasis on how to value and engage in such work" (Austin \& Barnes, 2005, p. 288).

\section{References}

Apple, M. W. (1982). Education and Power. Boston: Routledge and Kegan Paul.

Austin, A., \& Barnes, B. (2005). Preparing doctoral students for faculty careers that contribute to the public good. In A. J. Kezar, T. C. Chambers, \& J. C. Burkhardt (Eds.), Higher education for the public good (pp. 272-292). San Francisco: Jossey-Bass.

Baxter Magolda, M. B. (2006). Intellectual development in the college years. Change: The Magazine of Higher Learning, 38(3), 50-54. https://doi.org/10.3200/ CHNG.38.3.50-54

Boyer, E. L. (1990). Scholarship reconsidered: Priorities of the professoriate. Princeton, NJ: The Carnegie Foundation for the Advancement of Teaching.

Cech, E. A. (2014). Culture of disengagement in engineering education? Science, Technology, \& Human Values, 39(1), 42-72. https://doi. org/10.1177/0162243913504305

Cech, E. A., \& Sherick, H. M. (2015). Depoliticization and the structure of engineering education. In H. S. Christensen, C. Didier, A. Jamison, M. Meganck, C. Mitcham, \& B. Newberry (Eds.), International perspectives on engineering education: Engineering education and practice in context, Volume 1 (pp. 203-216). Cham, Switzerland: Springer International Publishing. https://doi.org/10.1007/978-3-319-16169-3_10

Damrosch, D. (2006). Vectors of change. In C. M. Golde \& G. E. Walker (Eds.), Envisioning the future of doctoral education: Preparing stewards of the discipline (pp. 34-45). San Francisco: Jossey-Bass.

DelNero, P., \& McGregor, A. (2017). From patients to partners. Science, 358(6361), 414. Retrieved from https://doi.org/10.1126/science.358.6361.414

Dewey, J. (1910). How we think. Boston: D.C. Heath \& Co.

Downey, G. L., \& Lucena, J. C. (1997). Engineering selves: Hiring into a contested field of education. In G. L. Downey \& J. Dumit (Eds.), Cyborgs and citadels: Anthropological interventions in emerging sciences and technologies (pp. 117-142). Santa Fe, NM: SAR Press.

Egan, J. M. (1989). Graduate school and the self: A theoretical view of some negative effects of professional socialization. Teaching Sociology, 17(2), 200-207.

Ellis, C. (2004). The ethnographic I: A methodological novel about autoethnography. Walnut Creek, CA: AltaMira Press. 
Ellis, C., Adams, T. E., \& Bochner, A. P. (2011). Autoethnography: An overview. Forum: Qualitative Social Research, 12(1), Art. 10.

Eyler, J., \& Giles, D. E. J. (1999). Where's the Learning in Service-Learning? San Francisco: Jossey-Bass.

Felten, P., Gilchrist, L. Z., \& Darby, A. (2006). Emotion and learning: Feeling our way toward a new theory of reflection in service-learning. Michigan Journal of Community Service Learning, 12(Spring), 38-46.

Gair, M., \& Mullins, G. (2001). Hiding in plain sight. In E. Margolis (Ed.), The hidden curriculum in higher education (pp. 21-41). New York: Routledge.

Gardner, S. K. (2008). Fitting the mold of graduate school: A qualitative study of socialization in doctoral education. Innovative Higher Education, 33(2), 125138. https://doi.org/10.1007/s10755-008-9068-x

Jackson, P. W. (1968). Life in classrooms. New York: Holt, Rinehart and Winston.

Kolb, D. A. (1984). Experiential learning: Experience as the source of learning and development. Upper Saddle River, NJ: Prentice Hall. Retrieved from https://doi. org/10.1016/B978-0-7506-7223-8.50017-4

Lawrence, C. R., \& Matsuda, M. J. (1997). We won't go back: Making the case for affirmative action. Boston: Houghton Mifflin.

Margolis, E., \& Romero, M. (1998). "The department is very male, very white, very old, and very conservative": The functioning of the hidden curriculum in graduate sociology departments. Harvard Educational Review, 68(1), 1-33. Retrieved from https://doi. org/10.17763/haer.68.1.1q3828348783j851

Margolis, E., \& Romero, M. (2001). "In the image and likeness ...": How mentoring functions in the hidden curriculum. In E. Margolis (Ed.), The hidden curriculum in higher education (pp. 79-96). New York: Routledge.

Mezirow, J. (1990). A transformation theory of adult learning. In P. Kleiber \& L. Tisdell (Eds.), Adult Education Research Annual Conference Proceedings (pp. 141-146). Athens, GA: University of Georgia.

Nash, R. J., \& Bradley, D. L. (2011). Me-search and research: A guide for writing scholarly personal narrative manuscripts. Charlotte, NC: Information Age Publishing.
Nyden, P. (2003). Academic incentives for faculty participation in community-based participatory research. Journal of General Internal Medicine, 18(7), 576-585. Retrieved from https://doi.org/10.1046/ j.1525-1497.2003.2035

Nyquist, J. D., Manning, L., Wulff, D. H., Austin, A. E., Sprague, J., Fraser, P. K., . . . Woodford, B. (2010). On the road to becoming a professor: The graduate student experience. Change: The Magazine of Higher Education, 31(3), 18-27. Retrieved from https://doi. org/10.1080/00091389909602686

O'Meara, K. (2008). Graduate education and community engagement. New Directions for Teaching and Learning, (113), 27-42. Retrieved from https://doi. org/10.1002/tl.306

Stanton, T. K. (2012). New times demand new scholarship II: Research universities and civic engagement: Opportunities and challenges. Journal of Higher Education Outreach and Engagement, 16(4), 271-304.

Strouse, A. W. (2014). Getting medieval on graduate education: Queering academic professionalism. Pedagogy: Critical Approaches to Teaching Literature, Language, Composition, and Culture, 15(1), 119-138. Retrieved from

https://doi.org/10.1215/15314200-2799260

Walker, G. E., Golde, C. M., Jones, L., Bueschel, A. C., \& Hutchings, P. (2008). The formation of scholars. San Francisco: Jossey-Bass.

Weidman, J. C., Twale, D. J., \& Stein, E. L. (2001). Socialization of graduate and professional students in higher education: A perilous passage? ASHE/ERIC Higher Education Report. San Francisco: Jossey-Bass.

\section{Author}

PETER DELNERO (pfd28@cornell.edu) is a doctoral candidate in the Nancy E. and Peter C. Meinig School of Biomedical Engineering at Cornell University. His current research focuses on public engagement in biomedical sciences and engineering. He is a recipient of the K. Patricia Cross Future Leaders Award from the Association of American Colleges and Universities (AAC\&U). 